\title{
PENGARUH LINGKUNGAN KERJA TERHADAP KEPUASAN KERJA PEGAWAI PADA KANTOR DINAS KELAUTAN DAN PERIKANAN PROVINSI SULAWESI TENGAH
}

\author{
MOHAMMAD RHAMADHANI SIDIK \\ IDRIS AZIS \\ WIRI WIRASTUTI \\ Jurusan Manajemen, Fakultas Ekonomi, Universitas Tadulako \\ Email: rhamadhanisidik.rs@gmail.com
}

\begin{abstract}
This study aims to determine the influence of Physical Work Environment and Non Physical Work Environment Against Job Satisfaction of Employees Office of Marine and Fisheries Office of Central Sulawesi Province. Independent variable of this research is Physical Work Environment $\left(X_{1}\right)$ and Non Physical Work Environment $\left(X_{2}\right)$. While the dependent variable is Job Satisfaction $(Y)$. The research method is quantitative descriptive method. The type of data used in this study is quantitative data while the data sources used are primary and secondary data. The population used in this study were 216 respondents. The sample of this research is 68 respondents with sampling technique that is proportional random sampling. Data analysis method used in this research is multiple linear regression analysis method. The results of this study indicate that the physical work environment and non physical work environment simultaneously affect the variable Job satisfaction. Partially the working environment of physical and non working physical environment have an effect on to job satisfaction of officer at office of Marine and Fishery Office of Central Sulawesi Province.
\end{abstract}

Keywords: physical work environment, non physical work environment, job satisfaction

\begin{abstract}
ABSTRAK
Penelitian ini bertujuan untuk mengetahui pengaruh Lingkungan Kerja Fisik dan Lingkungan Kerja Non Fisik Terhadap Kepuasan Kerja Pegawai Kantor Dinas Kelautan dan Perikanan Provinsi Sulawesi Tengah. Variabel independen penelitian ini adalah Lingkungan Kerja Fisik $\left(\mathrm{X}_{1}\right)$ dan Lingkungan Kerja Non Fisik $\left(\mathrm{X}_{2}\right)$. Sedangkan variabel dependen adalah Kepuasan Kerja $(\mathrm{Y})$. Metode penelitian adalah metode deskriptif kuantitatif. Jenis data yang digunakan dalam penelitian ini adalah data kuantitatif sedangkan sumber data yang digunakan adalah data primer dan sekunder. Populasi yang digunakan dalam penelitian ini sebanyak 216 responden. Sampel penelitian ini sebanyak 68 responden dengan teknik pengambilan sampel yaitu proportional random sampling. Metode analisis data yang digunakan dalam penelitian ini adalah metode analisis regresi linear berganda. Hasil penelitian ini menunjukkan bahwa lingkungan kerja fisik dan lingkungan kerja non fisik secara serempak berpengaruh terhadap variabel Kepuasan kerja. Secara parsial lingkungan kerja fisik dan lingkungan kerja non fisik berpengaruh terhadap kepuasan kerja pegawai pada kantor Dinas Kelautan dan Perikanan Provinsi Sulawesi Tengah.
\end{abstract}

Kata Kunci: lingkungan kerja fisik, lingkungan kerja non fisik, kepuasan kerja

\section{PENDAHULUAN}

Lingkungan Kerja yang produktif dan efisien akan mendorong seseorang bekerja secara maksimal sehingga akan dapat meningkatkan kepuasan kerja seseorang. Namun sebaliknya lingkungan kerja yang tidak produktif, efisien dan efektif bagi pegawai untuk bekerja tidak dapat diharapkan akan terjadi peningkatan kepuasan yang pada akhirnya akan berimplikasi secara luas tidak saja pada instituisi dimana pegawai bekerja. Supardi dalam (Muhammad, dkk, 2016) mendefinisikan lingkungan kerja merupakan keadaan sekitar tempat kerja baik secara fisik maupun secara non fisik yang dapat memberikan kesan menyenangkan, mengamankan, menentramkan dan kesan betah bekerja dan lain sebagainya. Penelitian terdahulu yang dilakukan oleh Lingga (2008) dalam (Wibowo, dkk, 2014) mengelompokan kedalam dua aspek faktor penentu kepuasan kerja karyawan yakni lingkungan fisik 
dan lingkungan non-fisik. Kedua aspek tersebut memiliki pengaruh secara signifikan terhadap kepuasan kerja.

Robbins (2001:179) menyatakan bahwa "Kepuasan kerja sebagai suatu sikap umum seorang individu terhadap pekerjaannya". Kepuasan kerja adalah suatu sikap umum terhadap pekerjaan seseorang sebagai perbedaan antara banyaknya ganjaran yang diterima pekerja dan banyaknya yang diyakini yang seharusnya diterima. Sedangkan menurut Greenberg dan Baron (2003:148) mendeskripsikan kepuasan kerja sebagai sikap positif atau negatif yang di lakukan individual terhadap pekerjaan mereka. Kepuasan kerja pada dasarnya merupakan sesuatu yang bersifat individual. Setiap individu memiliki tingkat kepuasan yang berbeda-beda sesuai dengan sistem nilai yang berlaku pada dirinya. Makin tinggi penilaian terhadap kegiatan dirasakan sesuai dengan keinginan individu, maka makin tinggi kepuasannya terhadap kegiatan tersebut. Dengan demikian, kepuasan merupakan evaluasi yang menggambarkan seseorang atas perasaan sikapnya senang atau tidak senang, puas atau tidak puas dalam bekerja.

Hasil observasi dan wawancara yang dilakukan di Dinas Kelautan dan Perikanan Provinsi Sulawesi Tengah terdapat permasalahan yang berkaitan dengan lingkungan kerja, baik itu lingkungan kerja fisik maupun lingkungan kerja non fisik. Untuk lingkungan kerja fisik yang masih menjadi masalah yaitu pada suhu ruangan seperti terdapatnya AC yang rusak di beberapa ruangan yang dapat membuat pegawai tidak nyaman dalam bekerja serta ventilasi yang kotor dan kurang terawat yang dapat berdampak pada kondisi kesehatan pegawai dan juga terdapat meja kerja yang tidak memiliki kursi serta terdapat ruang kerja yang sempit di beberapa ruangan. Sedangkan untuk lingkungan kerja non fisik yang masih menjadi masalah adalah hubungan antara atasan dan bawahan, dimana atasan jarang memberikan motivasi dan juga reward kepada bawahannya atas kinerja yang telah dicapainya, hal tersebut nantinya dapat mempengaruhi kepuasan kerja pegawai.

Hasil wawancara yang dilakukan dengan bapak S, selaku pegawai di Dinas Kelautan dan Perikanan Provinsi Sulawesi Tengah dalam hal yang berkaitan dengan kepuasan kerja pegawai antara lain pekerjaan itu sendiri, pengawasan, kelompok kerja, promosi, gaji dan kondisi kerja. Pertama mengenai pekerjaan itu sendiri, sebagian pegawai di Dinas Kelautan dan Perikanan Provinsi Sulawesi Tengah ini bekerja tidak sesuai bidang atau keahliannya. Kedua mengenai pengawasan, Pimpinan jarang memberikan motivasi atau reward kepada bawahannya padahal hal tersebut dapat berguna untuk meningkatkan kepuasan kerja serta produktivitas pegawai, yang ketiga mengenai kelompok kerja, ada sebagian pegawai kurang koordinasi atau kerja samanya dalam menyelesaikan tugas yang diberikan. Selanjutnya mengenai promosi, promosi jabatan di instansi ini kadang ditentukan berdasarkan kinerja namun terkadang juga berdasarkan faktor kedekatan dengan pimpinan dan ada pula pegawai dipromosikan tanpa sepengetahuan pimpinan. Selanjutnya mengenai gaji, di instansi ini gaji selalu dibayarkan tepat waktu, namun yang menjadi masalah adalah jika pegawai (PNS) tidak hadir atau tidak masuk kerja maka tunjangannya akan dipotong $1,2 \%$ sedangkan untuk pegawai honorer yang tidak masuk kerja akan dikenakan sanksi sesuai dengan kebijakan pimpinan.

Berdasarkan latar belakang masalah di atas, maka tujuan yang ingin dicapai dari penelitian ini adalah: 1) Untuk mengetahui dan menganalisis apakah lingkungan kerja fisik dan lingkungan kerja non fisik secara serempak berpengaruh positif dan signifikan terhadap kepuasan kerja pegawai pada Kantor Dinas Kelautan dan Perikanan Provinsi Sulawesi Tengah, 2) Untuk mengetahui dan menganalisis apakah lingkungan kerja fisik berpengaruh positif dan signifikan terhadap kepuasan kerja pegawai pada Kantor Dinas Kelautan dan Perikanan Provinsi Sulawesi Tengah, 3) Untuk mengetahui dan menganalisis apakah lingkungan kerja non fisik berpengaruh positif dan signifikan terhadap kepuasan kerja pegawai pada Kantor Dinas Kelautan dan Perikanan Provinsi Sulawesi Tengah. 


\section{KAJIAN LITERATUR DAN PENGEMBANGAN HIPOTESIS}

\section{Pengertian Lingkungan Kerja}

Kondisi lingkungan kerja sangat berpengaruh terhadap kepuasan kerja pegawai. Lingkungan kerja merupakan suatu lingkungan dimana para pegawai bekerja dan dapat mempengaruhi mereka dalam menjalankan tugas tugas yang dibebankan. Faktor-faktor yang termasuk lingkungan kerja adalah pewarnaan, kebersihan, pertukaran udara, penerangan, musik, kebisingan, ruang gerak dan hubungan antara pegawai atau pegawai dengan atasan

Lingkungan kerja yang baik akan memberikan kenyamanan pribadi maupun dalam membangkitkan semangat kerja pegawai sehingga dapat mengerjakan tugas-tugas dengan baik. Disamping itu pegawai akan lebih senang dan nyaman dalam bekerja apabila fasilitas yang ada dalam keadaan bersih, tidak bising, pertukaran udara yang cukup baik dan peralatan yang memadai serta relatif modern.

Kondisi kerja yang mendukung diartikan sebagai kepedulian pegawai akan lingkungan kerja baik untuk kenyamanan pribadi maupun untuk memudahkan mengerjakan tugas dengan baik, mereka cenderung lebih menyukai lingkungan fisik yang aman dan nyaman. Temperatur, cahaya, derau, dan faktor-faktor lingkungan lainnya, seharusnya tidak terlalu ekstrem (terlalu banyak atau terlalu sedikit) seperti misalnya terlalu panas, terlalu remang-remang. Secara umum kondisi lingkungan biasanya tidak terlalu berpengaruh terhadap kepuasan kerja selama tidak benar benar buruk.

Lingkungan kerja terbagi menjadi dua yaitu ada lingkungan kerja fisik dan lingkungan kerja non fisik. Lingkungan kerja fisik menurut Nitisemito (2000) adalah segala sesuatu yang ada disekitar para pekerja yang dapat mempengaruhi dirinya dalam menjalankan tugas-tugas yang diembankan, sedangkan lingkungan kerja non fisik menurut Sihombing (2004) adalah faktor-faktor diluar manusia mencakup hubungan kerja yang terbentuk di instansi antara atasan dan bawahan serta antar sesama pegawai.

\section{Dimensi Lingkungan Kerja Fisik}

Dimensi variabel lingkungan kerja fisik menggunakan teori dari Nitisemito (2000), yaitu:

1. Warna, menata warna di tempat kerja perlu dipelajari dan direncanakan dengan sebaikbaiknya. Sifat dan pengaruh warna kadang-kadang menimbulkan rasa senang, sedih, dan lain-lain, karena dalam sifat warna dapat merangsang perasaan manusia.

2. Kebersihan, kebersihan di tempat kerja harus selalu diperhatikan, karena dapat membuat pegawai merasa nyaman dan betah berada di tempat kerja serta dapat meningkatkan semangat dan kepuasan kerja pegawai sehingga pegawai dapat bekerja lebih baik.

3. Sirkulasi udara, oksigen merupakan gas yang dibutuhkan oleh makhluk hidup untuk menjaga kelangsungan hidup, yaitu untuk proses metabolisme.

4. Penerangan, cahaya atau penerangan sangat besar manfaatnya bagi pegawai guna mendapatkan kelancaran dan keselamatan kerja.

5. Keamanan kerja, yaitu guna menjaga tempat dan kondisi lingkungan kerja tetap dalam keadaan aman maka perlu diperhatikan adanya keberadaannya. Salah satu upaya untuk menjaga keamanan ditempat kerja, dapat memanfaatkan tenaga Satuan Petugas Keamanan (SATPAM).

\section{Dimensi Lingkungan Kerja Non Fisik}

Dimensi variabel lingkungan kerja non fisik menggunakan teori dari Sihombing (2004), yaitu :

1. Hubungan kerja antara atasan dan bawahan, sikap atasan terhadap bawahan memberikan berpengaruh terhadap pegawai dalam melaksanakan aktivitas-nya. Sikap yang bersahabat dan saling menghormati diperlukan dalam hubungan antara atasan dan bawahan untuk bekerja sama mencapai tujuan perusahaan.

2. Hubungan antar sesama pegawai, hubungan kerja antar sesama pegawai sangat diperlukan dalam melakukan pekerjaan, terutama bagi pegawai yang bekerja secara berkelompok. Konflik dapat memper-keruh suasana kerja sehingga berdampak pada penurunan motivasi kerja pegawai. 
Hubungan kerja yang baik antara sesama pegawai dapat meningkatkan motivasi pegawai dalam menyelesaikan pekerjaannya.

\section{Pengertian Kepuasan Kerja}

Setiap orang yang bekerja mengharapkan memperoleh kepuasan dari tempatnya bekerja. Kepuasan kerja akan mempengaruhi produktivitas yang sangat diharapkan oleh pimpinan. Untuk itu, pimpinan perlu memahami apa yang harus dilakukan untuk menciptakan kepuasan kerja pegawainya. Kepuasan kerja pada dasarnya merupakan sesuatu yang bersifat individual. Setiap individu memiliki tingkat kepuasan yang berbeda-beda sesuai dengan sistem nilai yang berlaku pada dirinya. Makin tinggi penilaian terhadap kegiatan dirasakan sesuai dengan keinginan individu, maka makin tinggi kepuasannya terhadap kegiatan tersebut. Dengan demikian, kepuasan merupakan evaluasi yang menggambarkan seseorang atas perasaan sikapnya senang atau tidak senang, puas atau tidak puas dalam bekerja.

Luthans (2006) kepuasan kerja adalah keadaan emosi yang senang atau emosi positif yang berasal dari penilaian pekerjaan atau pengalaman kerja seseorang, sementara Robbins (2001:179) menyatakan bahwa "Kepuasan kerja sebagai suatu sikap umum seorang individu terhadap pekerjaannya". Kepuasan kerja adalah suatu sikap umum terhadap pekerjaan seseorang sebagai perbedaan antara banyaknya ganjaran yang diterima pekerja dan banyaknya yang diyakini yang seharusnya diterima.

Menurut Greenberg dan Baron (2003:148) kepuasan kerja sebagai sikap positif atau negatif yang di lakukan individual terhadap pekerjaan mereka. Selanjutnya Vecchio (1995:124), menyatakan kepuasan kerja sebagai pemikiran, perasaan, dan kecenderungan tindakan seseorang, yang merupakan sikap seseorang terhadap pekerjaan.

\section{Dimensi Kepuasan Kerja}

Dimensi variabel kepuasan kerja menggunakan teori dari Luthans (2006), yaitu:

1. Pekerjaan itu sendiri, setiap pekerjaan memerlukan suatu keterampilan tertentu sesuai dengan bidangnya masing-masing. Sukar tidaknya suatu pekerjaan serta perasaan seseorang bahwa keahliannya dibutuhkan dalam melakukan pekerjaan tersebut, akan meningkatkan atau mengurangi kepuasan kerja.

2. Pengawasan, Pengawasan merupakan sumber penting lain dari kepuasan kerja. Terdapat dua dimensi gaya pengawasan yang memengaruhi kepuasan kerja, yang pertama adalah berpusat pada karyawan dan dimensi yang lain adalah partisipasi atau pengaruh, seperti diilustrasikan oleh manajer yang memungkinkan orang untuk berpartisipasi dalam pengambilan keputusan.

3. Kelompok kerja, rekan kerja atau anggota tim yang kooperatif merupakan sumber kepuasan kerja yang paling sederhana pada karyawan secara individu. Kelompok kerja, terutama tim yang kuat bertindak sebagai sumber dukungan, kenyamanan, nasihat, dan bantuan pada anggota individu.

4. Promosi, promosi merupakan faktor yang berhubungan dengan ada tidaknya kesempatan untuk memperoleh peningkatan karir selama bekerja.

5. Gaji, gaji merupakan faktor pemenuhan kebutuhan hidup pegawai yang dianggap layak atau tidak.

6. Kondisi kerja, efek lingkungan kerja pada kepuasan kerja sama halnya dengan efek kelompok kerja. Jika segalanya berjalan baik, tidak ada masalah kepuasan kerja. 


\section{Kerangka Pemikiran}

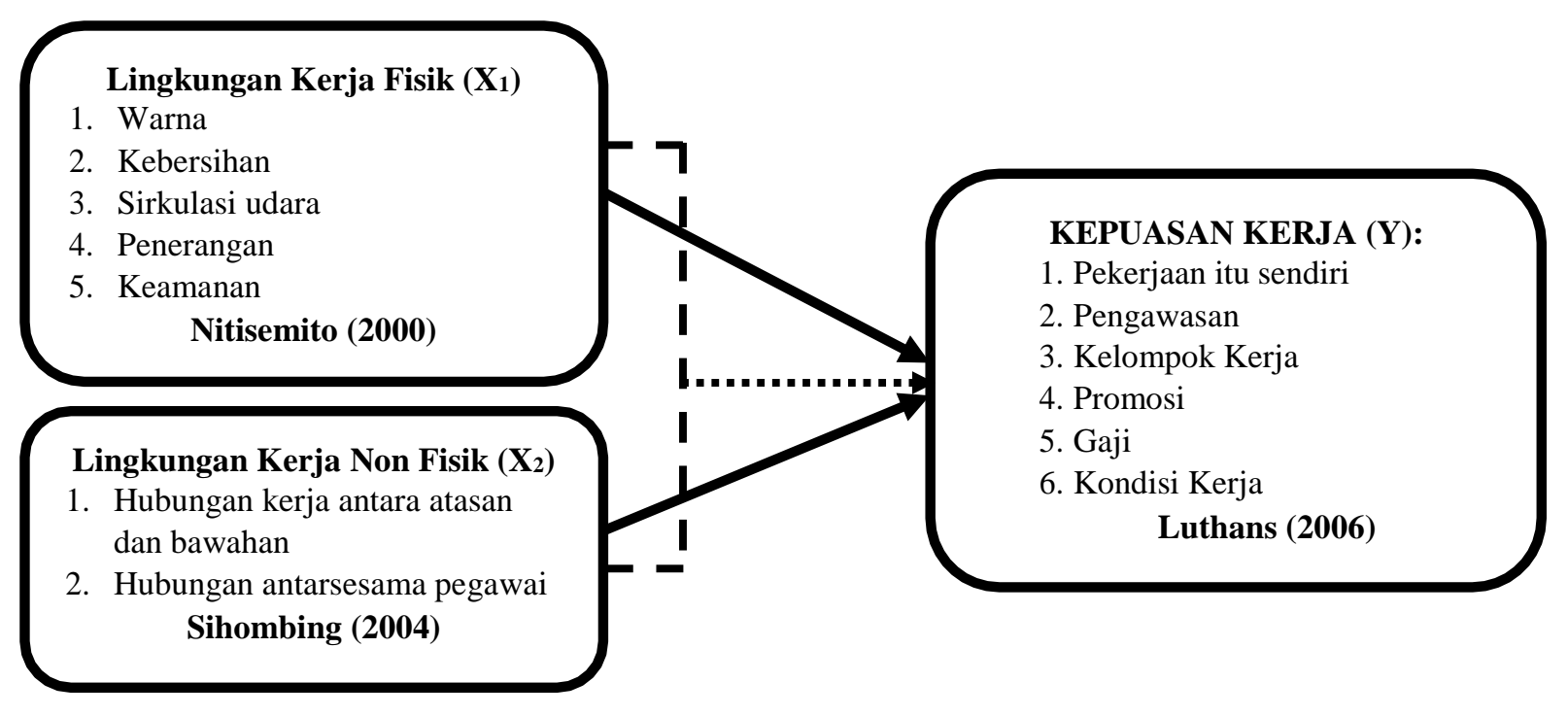

\section{Hipotesis}

\section{Gambar 1 Kerangka Pemikiran}

Berdasarkan tujuan serta dukungan landasan teori diatas maka dalam penelitian ini dapat ditarik suatu hipotesis sebagai kerangka acuan sebagai berikut:

1. Lingkungan kerja fisik dan lingkungan kerja non fisik secara serempak berpengaruh positif dan signifikan terhadap kepuasan kerja pegawai pada kantor Dinas Kelautan dan Perikanan Provinsi Sulawesi Tengah.

2. Lingkungan kerja fisik berpengaruh positif dan signifikan terhadap kepuasan kerja pegawai pada kantor Dinas Kelautan dan Perikanan Provinsi Sulawesi Tengah.

3. Lingkungan kerja non fisik berpengaruh positif dan signifikan terhadap kepuasan kerja pegawai pada kantor Dinas Kelautan dan Perikanan Provinsi Sulawesi Tengah.

\section{METODE PENELITIAN}

Jenis penelitian yang digunakan dalam penelitian ini adalah deskriptif dan kuantitatif. Menurut Sugiyono (2014:147) metode deskriptif adalah metode yang digunakan untuk mendeskripsikan atau menggambarkan data yang terkumpul sebagaimana adanya tanpa bermaksud membuat kesimpulan yang berlaku untuk umum. Penelitian ini mendeskripsikan pengaruh hubungan variabel bebas (lingkungan kerja fisik dan lingkungan kerja non fisik) terhadap variabel terikat (Kepuasan Kerja) pada Kantor Dinas Kelautan dan Perikanan Provinsi Sulawesi Tengah. Penelitian kuantitatif dalam melihat pengaruh/hubungan antar variabel terhadap objek yang diteliti lebih bersifat sebab akibat (kausal), sehingga dalam penelitiannya terdapat variabel independen dan variabel dependen. Dari variabel tersebut selanjutnya di cari sebesar besar pengaruh variabel independen terhadap variabel dependen.

Lokasi penelitian ini bertempat pada kantor Dinas Kelautan dan Perikanan Provinsi Sulawesi Tengah jalan Undata No 7 Kota Palu, selanjutnya teknik pengumpulan data yang digunakan dalam penelitian ini adalah: 1) Observasi, menurut Arikunto (2014:199) yaitu kegiatan pemuatan perhatian terhadap sesuatu objek dengan menggunakan seluruh alat indra. Jadi, observasi dapat dilakukan melalui penglihatan, penciuman, pendengaran, peraba, dan pengecap, 2) Wawancara/interview, menurut Arikunto (2014:198) yaitu sebuah dialog yang dilakukan oleh pewawancara. untuk mendapatkan informasi dari terwawancara, 3) Kuesioner, menurut Arikunto (2014:194) yaitu sejumlah pertanyaan tertulis yang digunakan untuk memperoleh informasi dari responden dalam arti laporan tentang pribadinya, atau hal-hal yang ia ketahui. 
Teknik pengambilan sampel dalam penelitian ini dilakukan dengan teknik proportional random sampling. Teknik ini digunakan bila populasi mempunyai anggota atau unsur yang tidak homogen dan berstrata secara proporsional (Sugiyono 2014:82). Adapun rumus teknik pengambilan sampel secara proportional random sampling yaitu sebagai berikut:

Atas dasar rumus di atas, maka dapat dihitung jumlah sampel penelitian sebagai berikut:

Tabel di bawah ini menunjukkan jumlah responden sebagai berikut:

Tabel 1

Jumlah Sampel Tiap Bagian Dinas Kelautan dan Perikanan Provinsi Sulawesi Tengah

\begin{tabular}{|c|l|l|c|}
\hline No & \multicolumn{1}{|c|}{ Bagian } & \multicolumn{1}{c|}{ Rumus } & Jumlah \\
\hline 1 & Sekretariat & $54 / 216=0,25 \times 68=17$ & 17 \\
\hline 2 & Perikanan Tangkap & $28 / 216=0,12 \times 68=8,81$ & 9 \\
\hline 3 & Perikanan Budidaya \& P2HP & $44 / 216=0,20 \times 68=13,85$ & 14 \\
\hline 4 & Pengelolaan Ruang Laut & $24 / 216=0,11 \times 68=7,55$ & 7 \\
\hline 5 & Pengawasan SDKP & $25 / 216=0,11 \times 68=7,87$ & 8 \\
\hline 6 & LPPMHP & $37 / 216=0,17 \times 68=11,64$ & 12 \\
\hline 7 & Penyuluhan Perikanan & $4 / 216=0,01 \times 68=1,25$ & 1 \\
\hline & Jumlah & & 68 \\
\hline
\end{tabular}

Metode analisis regresi linier berganda menurut Sugiyono (2014:277), analisis regresi linear berganda digunakan oleh peneliti bila peneliti bermaksud meramalkan bagaimana keadaan (naik turunnya) variabel dependen (kriterium), bila dua atau lebih variabel independen sebagai faktor prediktor dimanipulasi (di naik turunkan nilainya). Persamaan regresi linear berganda dalam penelitian ini adalah:

Keterangan:

$$
\mathbf{Y}=\mathbf{a}+\mathbf{b}_{1} \mathbf{X}_{1}+\mathbf{b}_{2} \mathbf{X}_{2}+\mathbf{e}
$$

$Y \quad=$ Kepuasan kerja

$a \quad=$ Konstanta

$b_{1} \quad=$ Koefisien regresi lingkungan kerja fisik

$b_{2} \quad=$ Koefisien regresi lingkungan kerja non fisik

$X_{1} \quad=$ Lingkungan kerja fisik

$X_{2} \quad=$ Lingkungan kerja non fisik

$e \quad=$ error / variabel pengganggu

\section{HASIL DAN PEMBAHASAN}

Tabel 2 Regresi Linear Berganda

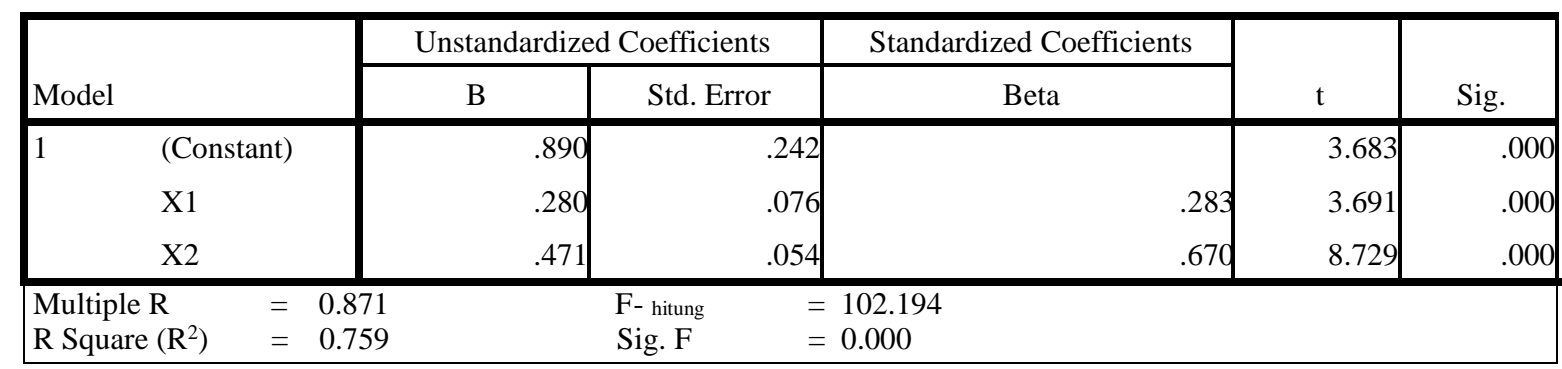


Berdasarkan Tabel 2, maka persamaan regresi linear berganda dirumuskan berikut:

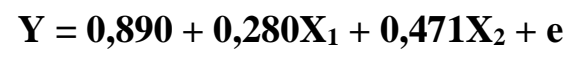

Berdasarkan persamaan tersebut maka dapat dinyatakan bahwa variabel independen $\left(\mathrm{X}_{1}\right.$ dan $\left.\mathrm{X}_{2}\right)$ memberi pengaruh positif terhadap variabel dependen $(\mathrm{Y})$.

a. Untuk nilai konstanta sebesar 0,890 berarti kepuasan kerja pada kantor Dinas Kelautan dan Perikanan Provinsi Sulawesi Tengah sebelum adanya variabel independen adalah sebesar 0,890

b. Nilai koefisien regresi variabel lingkungan kerja fisik (X1) bernilai positif yaitu 0.280 atau $28 \%$. Hal ini menyatakan bahwa nilai lingkungan kerja fisik meningkat maka akan meningkatkan kepuasan kerja pegawai kantor Dinas Kelautan dan Perikanan Provinsi Sulawesi Tengah.

c. Nilai koefisien regresi variabel lingkungan kerja non fisik (X2) bernilai positif yaitu 0.471 atau 47,1\%. Hal ini menyatakan bahwa nilai lingkungan kerja non fisik meningkat maka akan meningkatkan kepuasan kerja pegawai kantor Dinas Kelautan dan Perikanan Provinsi Sulawesi Tengah.

d. Nilai error atau variabel pengganggu adalah sebesar 0,241 atau 24,1\%. Hal ini menyatakan bahwa variabel kepuasan kerja dipengaruhi oleh variabel pengganggu yang tidak ada dalam penelitian ini yaitu sebesar $24,1 \%$

\section{Uji F}

Uji F bertujuan untuk mengetahui apakah variabel independen yakni lingkungan kerja fisik dan lingkungan kerja non fisik yang diteliti memiliki pengaruh secara serempak terhadap variabel dependen yakni kepuasan kerja pegawai pada kantor Dinas Kelautan dan Perikanan Provinsi Sulawesi Tengah. Berdasarkan Tabel 2 terlihat nilai signifikansi $\mathrm{F}=0,000<0,05$. Kesimpulannya adalah variabel bebas secara bersama-sama (serempak) berpengaruh signifikan terhadap variabel terikat, artinya bahwa variabel lingkungan kerja fisik dan lingkungan kerja non fisik secara bersama-sama (serempak) berpengaruh positif dan signifikan terhadap variabel kepuasan kerja pegawai pada kantor Dinas Kelautan dan Perikanan Provinsi Sulawesi Tengah.

\section{Uji t}

Uji t digunakan untuk mengetahui apakah variabel independen yakni lingkungan kerja fisik dan lingkungan kerja non fisik yang diteliti memiliki pengaruh secara parsial terhadap variabel dependen kepuasan kerja pegawai pada kantor Dinas Kelautan dan Perikanan Provinsi Sulawesi Tengah. Adapun hasil uji hipotesis secara parsial dapat dilihat sebagai sebagai berikut:

1. Lingkungan kerja fisik $\left(X_{1}\right)$. Berdasarkan Tabel 2 variabel lingkungan kerja fisik memiliki tingkat signifikansi t sig. $(0,000)<\alpha(0,05)$. Hal ini menunjukkan bahwa lingkungan kerja fisik berpengaruh signifikan terhadap kepuasan kerja pegawai kantor Dinas Kelautan dan Perikanan Provinsi Sulawesi Tengah.

2. Lingkungan kerja non fisik $\left(\mathrm{X}_{2}\right)$. Berdasarkan Tabel 2 variabel lingkungan kerja non fisik memiliki tingkat signifikansi t sig. $(0.000)<\alpha(0,05)$. Hal ini menunjukkan bahwa lingkungan kerja non fisik berpengaruh signifikan terhadap kepuasan kerja pegawai kantor Dinas Kelautan dan Perikanan Provinsi Sulawesi Tengah.

\section{Koefisien Determinasi $\left(\mathbf{R}^{2}\right)$}

Berdasarkan Tabel 2 di atas, diperoleh uji determinasi (kehandalan model) memperlihatkan nilai $R$ Square $=0,759$ atau 75,9\%. Artinya bahwa sebesar 75,9\% variabel kepuasan kerja pegawai pada kantor Dinas Kelautan dan Perikanan Provinsi Sulawesi Tengah dipengaruhi oleh variabel dependen, sedangkan sisanya 24,1\% variabel kepuasan kerja pegawai pada kantor Dinas Kelautan dan Perikanan Provinsi Sulawesi Tengah dipengaruhi variabel bebas lain yang tidak diteliti. 


\section{Pembahasan Penelitian}

Pengaruh Lingkungan Kerja Fisik dan Non Fisik Terhadap Kepuasan Kerja Pegawai Pada Kantor Dinas Kelautan dan Perikanan Provinsi Sulawesi Tengah

Berdasarkan hasil penelitian yang telah dilakukan pada Dinas Kelautan dan Perikanan Provinsi Sulawesi Tengah diketahui bahwa variabel lingkungan kerja fisik dan lingkungan kerja non fisik berpengaruh signifikan secara serempak terhadap kepuasan kerja Dinas Kelautan dan Perikanan Provinsi Sulawesi Tengah. Hal ini mengambarkan bahwa semakin baik lingkungan kerja fisik dan lingkungan kerja non fisik maka akan menciptakan suatu pekerjaan yang menyenangkan untuk dikerjakan, sehingga akan menimbulkan rasa kepuasan kerja pada pegawai. Pegawai yang puas akan lebih loyal terhadap instansi, sehingga dengan demikian pegawai dapat melaksanakan tugas dan tanggung jawabnya dengan baik.

Sedarmayanti (2011) mengatakan bahwa Lingkungan kerja fisik merupakan semua keadaan yang berbentuk fisik yang terdapat disekitar pegawai, yang dapat mempengaruhi pegawai tersebut baik secara langsung maupun tidak langsung. Lingkungan kerja fisik ada yang berupa lingkungan umum, dapat juga disebut dengan lingkungan kerja yang mempengaruhi kondisi manusia, seperti temperatur, kelembaban, dan sirkulasi udara. Sedangkan lingkungan kerja non fisik merupakan suatu keadaan yang terjadi dan memiliki kaitan dengan hubungan kerja, baik hubungan dengan atasan ataupun hubungan antarasesama rekan kerja

Hasil dari penelitian ini didukung oleh hasil penelitian yang dilakukan oleh Eka, dkk (2016) yang berjudul "Pengaruh lingkungan kerja fisik dan non fisik terhadap kepuasan kerja dan kinerja karyawan (Studi pada karyawan PT Telkom Indonesia Witel Jatim Selatan Malang) hasil penelitian tersebut menyatakan bahwa lingkungan kerja fisik dan lingkungan kerja non fisik secara simultan berpengaruh signifikan terhadap kepuasan kerja karyawan artinya penelitian yang dilakukan oleh Eka, dkk (2016) memiliki kesamaan dengan penelitian ini yaitu pada variabel lingkungan kerja fisik dan lingkungan kerja non fisik secara serempak berpengaruh signifikan terhadap kepuasan kerja. Berdasarkan hasil pengujian hipotesis disimpulkan bahwa lingkungan kerja fisik dan lingkungan kerja non fisik mempunyai pengaruh terhadap meningkatnya kepuasan kerja pada kantor Dinas Kelautan dan Perikanan Provinsi Sulawesi Tengah.

\section{Pengaruh Lingkungan Kerja Fisik Terhadap Kepuasan Kerja Pegawai Pada Kantor Dinas Kelautan dan Perikanan Provinsi Sulawesi Tengah}

Berdasarkan hasil penelitian yang telah dilakukan pada Dinas Kelautan dan Perikanan Provinsi Sulawesi Tengah diketahui bahwa variabel lingkungan kerja fisik berpengaruh signifikan secara parsial terhadap kepuasan kerja pegawai Dinas Kelautan dan Perikanan Provinsi Sulawesi Tengah. Hal ini dapat dilihat dari hasil uji t yang menunjukkan bahwa tingkat signifikansi $\mathrm{t}$ sig yang diperoleh sebesar $0,000<\alpha 0,05$. Hal tersebut menunjukkan bahwa semakin baik lingkungan kerja fisik, maka akan menciptakan suatu pekerjaan yang menyenangkan untuk dikerjakan, sehingga akan menimbulkan rasa kepuasan kerja pada pegawai.

Pengaruh lingkungan kerja fisik terhadap kepuasan kerja pegawai pada Dinas Kelautan dan Perikanan Provinsi Sulawesi Tengah bernilai positif artinya jika lingkungan kerja fisik meningkat maka akan meningkatkan kepuasan kerja pegawai Dinas Kelautan dan Perikanan Provinsi Sulawesi Tengah. Hal ini menyatakan bahwa variabel lingkungan kerja fisik merupakan faktor penting dalam peningkatan kepuasan kerja pegawai di Dinas Kelautan dan Perikanan Provinsi Sulawesi Tengah. Karena dengan terciptanya lingkungan kerja fisik yang baik dan nyaman maka akan membuat pegawai merasa senang, nyaman, dan betah bekerja di Dinas Kelautan dan Perikanan Provinsi Sulawesi Tengah sehingga pegawai semangat dalam bekerja serta dapat melaksanakan tugasnya dengan baik dan dengan demikian akan mempermudah Dinas Kelautan dan Perikanan Provinsi Sulawesi Tengah dalam mencapai tujuannya. 
Penelitian ini juga diperkuat oleh pendapat Robbins (1996) ia menyatakan bahwa mayoritas karyawan lebih menyukai lingkungan kerja fisik yang bersih, nyaman, dan di dukung dengan peralatan modern. Pendapat tersebut memberikan sebuah gagasan bahwa lingkungan kerja fisik memiliki peran penting untuk menciptakan kepuasan kerja pegawai. Penelitian ini juga mendukung penelitian dari Hendri (2012) yang berjudul "Pengaruh Lingkungan Kerja Fisik dan Non Fisik terhadap Kepuasan Kerja Karyawan pada PT Asuransi Wahana Tata Cabang Palembang" hasil penelitian tersebut menyatakan bahwa lingkungan kerja fisik berpengaruh signifikan terhadap kepuasan kerja artinya bahwa semakin meningkat lingkungan kerja fisik maka akan meningkatkan kepuasan kerja. Penelitian Hendri (2012) dengan penelitian ini memiliki kesamaan yaitu lingkungan kerja fisik secara parsial berpengaruh signifikan terhadap kepuasan kerja. Berdasarkan hasil pengujian hipotesis dapat disimpulkan bahwa lingkungan kerja fisik mempunyai pengaruh terhadap meningkatnya kepuasan kerja pada kantor Dinas Kelautan dan Perikanan Provinsi Sulawesi Tengah. Berdasarkan hasil pengujian hipotesis dapat disimpulkan bahwa lingkungan kerja fisik mempunyai pengaruh terhadap meningkatnya kepuasan kerja pada kantor Dinas Kelautan dan Perikanan Provinsi Sulawesi Tengah.

\section{Pengaruh Lingkungan Kerja Non Fisik Terhadap Kepuasan Kerja Pegawai Pada Kantor Dinas Kelautan dan Perikanan Provinsi Sulawesi Tengah}

Berdasarkan hasil penelitian yang telah dilakukan pada Dinas Kelautan dan Perikanan Provinsi Sulawesi Tengah diketahui bahwa variabel lingkungan kerja non fisik berpengaruh signifikan secara parsial terhadap kepuasan kerja pegawai Dinas Kelautan dan Perikanan Provinsi Sulawesi Tengah. Hal ini dapat dilihat dari hasil uji t yang menunjukkan bahwa tingkat signifikansi $\mathrm{t}$ sig yang diperoleh sebesar $0,000<\alpha 0,05$. Hal tersebut menunjukkan bahwa semakin baik lingkungan kerja non fisik, maka akan menciptakan suatu pekerjaan yang menyenangkan untuk dikerjakan, sehingga akan menimbulkan rasa kepuasan kerja pada pegawai.

Pengaruh lingkungan kerja non fisik terhadap kepuasan kerja pegawai pada Dinas Kelautan dan Perikanan Provinsi Sulawesi Tengah bernilai positif artinya jika lingkungan kerja non fisik meningkat maka akan meningkatkan kepuasan kerja pegawai Dinas Kelautan dan Perikanan Provinsi Sulawesi Tengah. Hal ini menyatakan bahwa variabel lingkungan kerja non fisik merupakan faktor penting dalam peningkatan kepuasan kerja pegawai di Dinas Kelautan dan Perikanan Provinsi Sulawesi Tengah. Lingkungan kerja non fisik sangat mempengaruhi kepuasan kerja pegawai Dinas Kelautan dan Perikanan Provinsi Sulawesi Tengah, dimana keadaan atau situasi di sekitar pegawai Dinas Kelautan dan Perikanan Provinsi Sulawesi Tengah telah kondusif untuk bekerja, rekan mudah diajak bekerja sama dan hubungan dengan atasan baik sehingga pegawai akan menikmati pekerjaannya dan merasa puas bekerja

Penelitian ini juga diperkuat oleh pendapat Sedarmayanti (2011) yang menyatakan bahwa lingkungan kerja non fisik adalah semua keadaan yang terjadi yang berkaitan dengan hubungan kerja, baik hubungan dengan atasan maupun hubungan sesama rekan kerja, ataupun hubungan dengan bawahan. Maksud dari pendapat tersebut adalah apabila lingkungan kerja non fisik baik, maka akan menciptakan perasaan senang terhadap pekerjaannya sehingga akan menimbulkan rasa kepuasan kerja pada pegawai. Penelitian ini juga mendukung penelitian dari Hendri (2012) yang menyatakan bahwa lingkungan kerja non fisik berpengaruh signifikan terhadap kepuasan kerja. Berdasarkan hasil pengujian hipotesis dapat disimpulkan bahwa lingkungan kerja non fisik mempunyai pengaruh terhadap meningkatnya kepuasan kerja pada kantor Dinas Kelautan dan Perikanan Provinsi Sulawesi Tengah 


\section{KESIMPULAN DAN SARAN}

\section{Kesimpulan}

1. Lingkungan kerja fisik dan lingkungan kerja non fisik secara serempak berpengaruh positif dan signifikan terhadap kepuasan kerja pegawai pada kantor Dinas Kelautan dan Perikanan Provinsi Sulawesi Tengah.

2. Lingkungan kerja fisik berpengaruh positif dan signifikan terhadap kepuasan kerja pegawai pada kantor Dinas Kelautan dan Perikanan Provinsi Sulawesi Tengah.

3. Lingkungan kerja non fisik berpengaruh positif dan signifikan terhadap kepuasan kerja pegawai pada kantor Dinas Kelautan dan Perikanan Provinsi Sulawesi Tengah.

\section{Saran}

1. Disarankan kepada Dinas Kelautan dan Perikanan Provinsi Sulawesi Tengah agar lebih memperhatikan lingkungan kerja fisik khususnya kebersihan, untuk selalu menjaga kebersihan kantornya agar pegawai merasa nyaman dalam bekerja.

2. Disarankan kepada Dinas Kelautan dan Perikanan Provinsi Sulawesi Tengah agar lebih memperhatikan lingkungan kerja non fisik khususnya hubungan antara atasan dan bawahan, untuk lebih ditingkatkan lagi maksudnya adalah atasan atau pun bawahan harus saling menghormati satu sama lain, karena hubungan yang terjalin dengan rasa saling menghormati akan memberikan pengaruh yang positif bagi instansi.

3. Disarankan kepada Dinas Kelautan dan Perikanan Provinsi Sulawesi Tengah agar lebih memperhatikan kepuasan kerja pegawai khususnya dalam hal promosi jabatan, agar pimpinan melakukan promosi jabatan dengan adil bukan berdasarkan oleh faktor kedekatan tetapi harus berdasarkan faktor pengalaman, tingkat pendidikan, serta prestasi kerja.

\section{REFERENSI}

Arikunto, Suharsimi. (2014). Prosedur Penelitian: Suatu Pendekatan Praktik. Jakarta: PT.Rineka Cipta.

Eka, Bambang dan hamidah. (2016). Pengaruh Lingkungan Kerja Fisik dan Non Fisik Terhadap Kepuasan Kerja dan Kinerja Karyawan (Studi Pada Karyawan PT Telkom Indonesia Witel Jatim Selatan Malang). Jurnal Administrasi Bisnis (JAB), Vol.40, No.1, November 2016.

Peraturan Pemerintah (PP) Republik Indonesia Nomor 53 Tahun 2010 Tentang Disiplin Pegawai Negeri Sipil (PNS).

Greenberg, Jerald dan Robert A. Baron. (2003). Behavior in Organizations. New Jersey: Prentice Hall. Hendri, Edduar. (2012). Pengaruh Lingkungan Kerja Fisik dan Non Fisik terhadap Kepuasan Kerja Karyawan pada PT Asuransi Wahana Tata Cabang Palembang. Jurnal Media Wahana Ekonomika, Vol.9, No. 3.

Luthans, Fred. (2006). Perilaku Organisasi. Yogyakarta: Andi Offset.

Muhammad, Adolfina dan Lumintang. (2016). Pengaruh Lingkungan Kerja, Kompensasi dan Beban Kerja terhadap kinerja karyawan pada Dinas Pendapatan Daerah Kota Manado. Jurnal EMBA, Vol.4, No.1, Hal. 045-055.

Sihombing setiasi. (2004). Dasar Dasar Manajemen Sumber Daya Manusia. Bandung: Alfabeta.

Robbins, Stephen. P. (2001). Perilaku Organisasi . Jilid-I. Jakarta: PT. Prenhalindo.

Robbins, Stephen. P. (1996). Perilaku Organisasi. Jilid 1. Alih Bahasa Handoyo Pujoatmiko. Jakarta: Perhallindo.

Sedarmayanti. (2011). Sumber Daya Manusia, Reformasi Birokrasi dan Manajemen Pegawai Negeri Sipil ( cetakan kelima). Bandung: PT Refika Aditama.

Sugiyono. (2014). Metode Penelitian Bisnis. Bandung: Alfabeta.

Vecchio Robert P. (1995). Organizational Behavior. Florida: The Dryden Press.

Wibowo, Al Musadieq dan Nurtjahjono. (2014). Pengaruh Lingkungan Kerja Terhadap Kepuasan Kerja Karyawan (Studi pada Karyawan PT.Telekomunikasi Indonesia Tbk Kandatel Malang). Jurnal Administrasi Bisnis, Vol. 16, No.1, November 2016. 